\title{
Student Engagement, Ideological Contest and Elective Affinity: The Zepke thesis reviewed.
}

\author{
Paul Trowler, Lancaster University. Department of Educational Research, Lancaster \\ University, UK, LA1 4YD. p.trowler@lancaster.ac.uk
}

\begin{abstract}
This paper takes up issues raised in two articles by Nick Zepke (2014a and b) and portrayed here as 'the Zepke thesis'. This thesis argues that the literature on, interest in and practices around student engagement in higher education have an elective affinity with neo-liberal ideology. At one level this paper counters many of the assertions that underpin the Zepke thesis, challenging them as being based on a selective and tendentious interpretation of that literature. It also points out the misuse of the concept of 'elective affinity' within the thesis. However, more significantly the paper argues that an understanding of how ideas are taken up and used requires a more sophisticated ontological understanding than the Zepke thesis exhibits. That thesis has strayed into the territory of the sociology of knowledge while ignoring the accounts and debates in that area developed over more than a century.
\end{abstract}

\section{Key words}

Student engagement; elective affinity; neo-liberalism; higher education; ideology.

The ideas of the ruling class are in every epoch the ruling ideas... The class which has the means of material production at its disposal, has control at the same time over the means of mental production. (Marx, 1968).

\section{Introduction: The Zepke thesis}

The Zepke thesis of the title as set out in Zepke (2014a and b) makes the following set of propositions about research and writing on student engagement in higher education:

1. The literature is predominantly uncritical of the concept of student engagement.

2. It is myopic in two senses: first that it neglects the significance of context in understanding and applying that concept; second that it predominantly addresses engagement in relation to pedagogy and ignores curricular issues.

3. The approach taken in the literature has an affinity with and supports a neoliberal, commoditized, instrumental view of knowledge, performativity and accountability. This explains the current high profile that student engagement enjoys among policy bodies in higher education: it has "traction".

In summary, then, the thesis posits that the literature on student engagement is uncritical, myopic, ideologically homogeneous and supportive of the neo-liberal agenda which forms the underpinning ideological agenda of the 'global policy ensemble' (Ball, 2008). 
The purpose of this paper is not to offer a thorough critique of all aspects of the Zepke thesis. Rather it is to concentrate on the last issue, the claim that the research literature on student engagement has an affinity with and supports the neo-liberal agenda. I will however offer a few initial comments on the other aspects of the thesis because the last issue relies on assertions about the literature which are at best over-stated and at worst fallacious.

\section{An uncritical literature?}

Zepke (2014a, 2) addresses the idea that student engagement "seems to escape serious critique". There has developed an "uncritically accepted academic orthodoxy", he argues, deploying Brookfield's phrase $(1986,96)$. It is an orthodoxy which he wants to disrupt: it is time to give a critical perspective an airing in student engagement research. This is a difficult assertion to test because Zepke does not define the parameters of the student engagement literature, nor does he define 'student engagement' itself. As Trowler (2010) notes, most literature on education could be said to concern student engagement in one sense or another, and so a clear definition, or at least criteria for inclusion, is vital.

Although there is some merit in a claim of lack of criticality in specific areas in the majority of the relevant literature (Haggis, 2003), Zepke is constructing a straw man on this issue by being selective in representing the literature and by interpreting it one-sidedly. For example, Zepke does acknowledge that Krause (2012) takes a critical approach, but only in terms of reflective accountability instruments such as the Australasian Student Engagement Survey. Likewise he acknowledges 'specific' critiques elsewhere but concludes that “....despite these specific critiques, the construct [of student engagement] as an entity and the research that feeds it have escaped general criticism." (Zepke, 2014, 4).

In fact Krause's critique goes much deeper than the part of it cited by Zepke. Alongside a reading of engagement as analogous to "appointment" (as in, "I have an engagement at two o' clock" suggesting that for some students studying was merely one of many options to schedule in their calendars) she proposed that:

For some students, engagement with the university experience is like engaging in a battle, a conflict. These are the students for whom the culture of the university is foreign and at times alienating and uninviting. (Krause 2005, 9).

In similar fashion, Thomas's work is cited by Zepke (2014a), but not (in the part of the paper building the straw man) the critical elements of it; Zepke's selective focus here is on her 'What Works' research (2012), not the more theoretical papers (e.g. Thomas, 2002). One small output of one of the two projects Vicki Trowler and I conducted into student engagement is mentioned in Zepke 2014a, but only the pamphlet for leaders (HEA, 2010), not the 20,000 word literature review on student engagement (Trowler, 2010) which identifies critical literature. Mann's work for example is reviewed, being a well-theorized, critical account discussing the nature of "our current sociocultural condition" (Mann, 2001, 17) and its implications for student alienation and engagement. Slocum and Rhoads $(2008,102)$ are quoted: 
[We] offer a counter-narrative to the notion of the university as economic tool or academic haven. This counter-narrative provides a vision of the university as a vehicle for social transformation, whereby part of the university community is engaged in something other than the pursuit of immediate economic returns. Rather, they are directly involved in creating a vision of society based on more democratic economic practices and a politically engaged citizenry.

More recent work also identifies a critical literature. For example Wimpenny and Savin-Baden (2013) engaged in a progressively refined process of selecting articles on student engagement for analysis and found that 9 out of 56 papers chosen for close examination had the characteristic of taking "a critical stance", acknowledging "different versions of participants' identities" and being "theoretically situated" (Wimpenny and Savin-Baden, 2013, 315). Going further afield, there is a considerable literature around the relationship between students' ability and motivation to engage on the one hand and, on the other, academic literacies (for example Ivanic, 1998) and knowledge forms in universities and the differential cultural capital of students (Bourdieu, 1986).

\section{A myopic literature?}

Zepke claims the literature on student engagement is myopic in two ways. First, it neglects the significance of context in understanding and applying that concept, so that "Engagement researchers need to keep in mind more the impact of ethnicity, age, gender, socio-economic status, lifestyle and beliefs on engagement" (Zepke, 2014a, 8). Second, it predominantly addresses engagement in relation to pedagogy and ignores curricular issues, so that researchers need to "begin to accept the partial understanding of engagement offered by current engagement research” (Zepke, 2014a, 8). He says:

[The engagement literature] "focuses too much on a generic learner that neglects the impact of specific contexts".... "It is uncommon...to read engagement research that focuses on anything other than learning and teaching in the classroom or online....'. (Zepke, 2014a, 2).

I will briefly deal with each of these next.

\section{Myopia: Context}

Haggis (2003) makes a similar point to Zepke in looking at the "approaches to learning" research, describing the way its ethnocentrism makes it blind to the significance of other contexts:

Such descriptions appear to be blind to the epistemological, philosophical and cultural influences which underlie the research traditions within which the model has itself been created, and the way in which these are reflected in its structure, assumptions and value judgements. The lack of 'fit' between the model and these different cultural contexts could be seen as an indication of the deeper paradoxes and contradictions which exist within this overall conceptualisation of learning. (Haggis, 2003, 93).

In her 2006 paper Haggis says that assumptions about learning are often framed from the researcher's perspective, not actual students' perspectives. Students bring different histories and 
characteristics to a situation and so different definitions of the situation: ones which are very different from researchers', which tend to totalize the category 'student' and ignore these different understandings of context:

[W]hen viewed in relation to the 'initial conditions' of their lives (place, class, gender), and in relation to their specific histories (schooling, post-school learning, work history), the students are profoundly different from each other. (Haggis, 2006, 21).

It would appear that the Zepke thesis is correct in that the majority of that literature about student engagement is normative in approach and a fair proportion adopts a reductionist and essentialist view of 'the student', bracketing out difference (Haggis, 2006; Trowler, 2010). One example of reductionism is Harper and Quaye's contention $(2009,9)$ that minority groups of different sorts have homogeneous views about architecture or artwork for the walls of buildings..

However, there are a considerable number of exceptions, as is revealed by internal contradictions in Zepke (2014a). In his mapping of the field he says: "Research also offers multiple views on how students, teachers, institutions and the external environment facilitate engagement. One important difference is geographical." (Zepke, 2014a, 3). He cites Kahu (2013) who identifies the significance of antecedent circumstances for engagement. Zepke notes that strand of research which emphasizes the significance of "the whole of an institution's curriculum policies and practices" and another which identifies "non-institutional environments as an important facilitator of engagement." (Zepke, 2014a, 3). This somewhat undermines the claim that engagement research "focuses too much on an engaged generic learner that neglects the impact of specific contexts" (Zepke, 2014a, 1) and his axiom that "Engagement researchers could recognise contextual and personal diversity when researching engagement pedagogy" (Zepke, 2014a, 8).

Beyond Zepke's work itself, Case and Marshall (2005) offer a number of examples of studies that take context into account when applying the 'approaches to learning' theory, including Booth (1992), Drew et al (2002) and Case \& Marshall (2004). Wimpenny and Savin-Baden (2013) found many examples of awareness in the literature of how contextual contingencies condition the efficacy of engagement practices:

Studies have considered what institutions and educators can do to improve engagement (and retention) including the roles of institutional structures and cultures (Porter 2006); there is a focus on learning design and how educators practise and relate to their students (Haug 2006)...[S]tudent agency and motivation is recognised (Hockings et al. 2008); as is the impact of environmental factors such as family, relationships and economic status (Miliszewska and Horwood 2004). (Wimpenny and Savin-Baden, 2013, 312).

The North American National Survey of Student Engagement (NSSE) asks questions about engagement and diversity, including students' exposure to and experience of diversity. The most cited paper on student engagement in higher education (Kuh, 2003) uses NSSE data to interrogate issues of context and student diversity and the effectiveness of engagement practices across different institutional types. A final example is the Harper and Quaye book mentioned above. It shows that different populations of students (low-income, minority ethnicities, those with 
disabilities and so on) experience higher education differently and encounter group-specific barriers to success.

\section{Myopia: The full range of engagement areas}

The Zepke thesis argues that pedagogical issues predominate in the literature taken as a whole, taking a restricted view of the learning and teaching dimension of student engagement and ignoring other dimensions of engagement.

It is uncommon, for example, to read engagement research that focuses on anything other than on learning and teaching in the classroom or online learning environments. (Zepke, 2014a, 2).

This is why he argues that engagement researchers must learn to widen their view beyond pedagogy. One problem with such a concentration on pedagogy, argues Zepke, is that privileges pedagogy over curriculum:

which is a more philosophical and political understanding of purposes, knowledge and values in higher education. (Zepke, 2014a, 2).

So this myopic perspective connects to the lack of criticality and the unthinking connection to neo-liberal discourse, according to the thesis.

However, while Zepke is correct that learning and teaching issues dominate the literature, and that much of that literature fails to make connections between different dimensions of engagement, the case is based on a highly selective account and reading of the literature. In addition to pedagogical issues, areas of student identity and sense of belonging as well as engagement with higher education structures and processes are significant elements in the research and literature in the area. The distinction between the three areas of focus (pedagogy, identity and structure/process) is largely an analytical one: they are frequently linked. Ashwin and colleagues (2012) show how engagement with academic knowledge fosters identity change in sociology students. Carey's work (2013) shows how being involved in representing students' needs and interests within institutions can enhance engagement there more generally.

The Zepke allegation of myopia in the literature, then, overstates the case and offers a partial account of research in the area. The literature is heterogenous, with different understandings of the student engagement, units of analysis, levels of complexity and scale.

\section{Elective Affinity}

Zepke (2014a, 6) argues that "engagement research is so prominent because it shares values with a dominant political ideology" (Zepke, 2014a, 6). He claims that an "elective affinity" between neoliberal ideology and the viewpoint articulated in the engagement literature gives the latter "traction"; hence engagement's high profile. 
However this is based on a misreading of the idea of elective affinity. This is compounded by the errors of totalizing the literature on student engagement and ignoring the different social and policy contexts in which the various authors are situated.

Zepke is unclear about what exactly it is that has an 'elective affinity' with neo-liberalism. Looking across the two papers (2014a and b) there are claims that it is: "student engagement research"; "student engagement" (or sometimes just "engagement") and "interest in student engagement". These are quite different claims because "student engagement research" describes both a process and a product, enacted and produced by researchers as individuals and groups, while "student engagement" describes not the research but the process itself, involving students, staff of all sorts and institutional contexts. By contrast "interest in student engagement" describes a state of mind.

Underlying this vagueness is a misunderstanding of the nature of elective affinity. Again, across the two papers Zepke (citing Jost, Frederico and Napier, 2009) says it is a state created by forces of mutual attraction and that this attraction is between ideologies and social groups. But in the 2014b paper he also claims that Weber uses the term as shorthand for a close relationship between two ideas. Later Zepke explains that "(t)he relationship is elective because social groups seek new ideas, and new ideas in turn are attractive to sympathetic groups". Moreover this results in "the emergence of an accommodation, a mutual acceptance" - presumably between sympathetic groups (one imagines researchers, teachers and students) and neo-liberalism.

In fact though the term 'elective affinity' is originally Goethe's, its sociological use derives from Gerth and Mills' (1946) description of Weber's analysis of a particular social group of religious believers selectively adapting parts of a system of ideas over time, while at the same time modifying their own recurrent practices to align with those adapted ideas. The 'election' is to do with the ways in which the selections and adaptations are made and the resulting changes in practices. The 'affinities' are between particular parts of the system of ideas and the context and practices of that social group. The original system of ideas does not itself change (so there is no 'mutual acceptance' and no mutuality of attraction) - it is merely adapted selectively in a particular social context by a defined social group who select and interpret those parts of it which they find salient and somewhat congruent with their context, while at the same time refining their practices, attitudes and values to enhance affinities with it. The affinities grow stronger over time as the adapted ideas, needs, interests and practices find their fit. Other social groups in a different context may have no affinity with or interest in that system of ideas, or may adopt different patterns of election in terms of what is used, what forgotten and what reinterpreted; patterns which suit their own social context, needs and interests.

Gerth and Mills (1946) show the significance of elective affinity in the progressive development of Calvinist ideas and practices and how this created fertile ground for entrepreneurial capitalism. The spirit of capitalism, for Weber, involves a disciplined labour force together with the regularised investment of capital to improve and increase production. There is rational organisation of a formally free labour force for efficient production. Weber asks: how did this come about, and why predominantly in Protestant countries? A partial answer lies in the asceticism of Puritanism. The key to this is the notion of "the calling", involving the moral obligation of the individual to do his or her duty in the world, working hard but not for personal pleasure. The idea evolved because of a 
continuous process of selection and interpretation from the original doctrine in line with the needs and interests of the group and consequent behavioural changes. This was the progressive 'hardening' of an elective affinity. The original doctrine held that God's will is predetermined and unchangeable by humans. The names and number of those destined for heaven was already determined by God and permanently set. This doctrine led to an emotional state of loneliness and concern, a torment for the Puritan believers: they could not be sure they were not destined for eternal damnation. To deal with it the Calvinist response was to regard oneself as one of the 'chosen': a lack of certainty about this indicated insufficient faith. The performance of one's duty, 'good works', became a way of demonstrating certainty of being one of God's chosen, though nothing could affect God's will itself: the works were a sign of being among the chosen rather than a mechanism for making it so. The accumulation of wealth was an accidental by-product of this combination of hard work and asceticism in a community where self-indulgence, luxury and conspicuous consumption were denigrated. This laid the ground for the capitalist formation.

The significance here is the relationship between ideas and the social world. Weber's book can be seen as a contribution to the sociology of knowledge, which investigates the relationship between ideas and social formations. Weber is not just talking about the relationship between ideas and material interests (a simplistic version of Marxian ideas), but also between them and a state of mind: in this case the internal psychological torment of early Calvinists.

What is notable in this account is that there are different dimensions of affinity:

1. The affinity between the Protestant creed and the social circumstances at the time, allowing that creed to become popular in a context dominated by a different one: Catholicism. Without this affinity Protestantism would have died.

2. The hardening elective affinity between the interpreted Protestant creed and its followers' practices.

3. The affinity between the Protestant ethic and spirit of capitalism.

The process of election only occurs in the second. Gerth and Mills $(1946,63)$ carefully distinguish between elective affinity and simple congruence, the former only happening in the process of routinization by followers of time as they progressively 'elect' those features of the ideology with which they have an affinity.

So the idea of elective affinity does not presume a single dominant, unquestioned, set of ideas: certainly the Catholics questioned the Protestant creed, often with deadly results, and Protestantism itself experienced multiple schisms. Nor does it assume that elective affinity is homogeneous and universal: the process of election is context-specific and involves struggle. There is no assumption of mutual accommodation between the social group doing the electing and the original set of ideas; indeed the notion of neo-liberalism accommodating to or "accepting" student engagement research in some way is ludicrous.

Weber is careful about his claims and tentative about his conclusions: that the ascetic practices and ethic of the Protestants formed a foundation in which capitalism could thrive. Zepke is more cavalier. In the Zepke thesis the concept of student engagement "has gained its high profile because it aligns with and supports a neoliberal ideology" (Zepke, 2014a, 2). 
What is missing from the Zepke thesis is a deconstruction of the different social groups for which the notion of and literature on student engagement is pertinent, and the different sets of interests and contextual features which shape what they take from it and how they use it. The situation is not an homogeneous one with neo-liberalism rampant. It is complex and contested, with a dynamic configuration of interests and 'takes' on student engagement in higher education. Instead Zepke offers a simplistic ontological and epistemological account resting on an implicit sociological view of people as puppets of social structures, on the model of 'homo sociologicus' as this view has classically been described.

Missing too is the idea of any affinity being 'elective' - the process of selection and interpretation that occurs over time. There is simply an account of affinity between engagement research and neo-liberalism in that they share:

[A]n approach to knowledge that makes it largely invisible in the engagement discourse, a view of learning that emphasises outcomes and performance, and a view of quality that is informed by accountability measures. (Zepke, 2014a, 6).

Also:

$[T]$ hat what is to be learnt is practical and economically useful in the market place; that learning is about performing in certain ways in order to achieve specified outcomes; and that quality is assured by measurable accountability processes. (Zepke, 2014b, online).

These offer static accounts of a situation, not a process of election. And while neo-liberalism is recognizable in these depictions (though not the 'invisibility of knowledge' in it), student engagement research taken as a whole is not.

One possible argument that does involve elective affinity would be to say that from a chaotic conception (Trowler, 2014) such as student engagement certain elements are selected and interpreted by researchers so that only those elements and those interpretations gain dominance. Over time 'student engagement' comes to mean only one thing, something that has found a progressively better 'fit' with the needs and interests of researchers. The processes of election involved in this would be guided by neo-liberal ideology and discourse among these researchers. But to claim this would be to assert that educational researchers as a group subscribe to that ideology, which is not sustainable given the critical literature from them about it (Shumar, 1997; Molesworth et al, 2011; Brown with Corasso, 2013; Marginson, 2013) and its close relative, new managerialism (Deem et al, 2008).

The accounts quoted immediately above are also fundamentally erroneous even as descriptions. It is not difficult to find instances which seem to confirm them: the British Quality Assurance Agency's (QAA) chapter on student engagement (chapter B5: QAA, 2012) with its Expectation in this regard for higher education institutions and its various Indicators underlying that. But it is not difficult either to find counter-instances: the British National Union of Students (NUS) takes a completely different approach to the QAA. It prefers the term 'partnership' over 'engagement' and sets out a radical agenda in its Manifesto for Partnership (NUS, 2014) which envisages students participating with university staff equally in the whole range of decision-making at universities, including pedagogy, policy and resource allocation. The manifesto explicitly rejects a consumerist 
model of engagement as superficial and as propagating an erroneous view of higher education as something that can be packaged and sold. It engages in an extended critique of the QAA student engagement chapter and proposes an alternative approach. It rejects each of the descriptions in the two quotes from Zepke immediately above. The manifesto says:

Listening to and seeking feedback from individual students, after all, sits neatly in a consumer model. It is only when students are enabled to contribute to educational and institutional change that partnership is happening. (NUS, 2014, 3)

This partnership model is enacted at the University of Lincoln in the UK in many different ways (University of Lincoln, 2014) including through action research, policy and practice. Similarly Birmingham City University enacts a partnership model of student engagement, the philosophy and practice of which is outlined in and exemplified by the staff-student collaborative book edited by Nygaard et al (2013). From this perspective the partnership of institution, staff and students brings a sense of ownership, belonging and enhanced learning in ways that cannot occur in a marketised setting in which students consume a commoditised version of knowledge.

These are not isolated instances. Many student engagement researchers challenge the neo-liberal market ideology which positions the student as consumer. Instead they argue for a 'developmental' model of higher education, rooted in a 'progressivist' ideology, not an 'enterprise' one (Trowler, 1998). Far from adopting a commoditized view of knowledge, much research takes a constructivist/social learning view of it (Wintrup, 2014). Far from only emphasizing successful completion of courses, the research often emphasizes individual identity change in students (Ashwin, 2012). Far from uncritically accepting accountability measures, much of the engagement literature attacks them (Sabri, 2013). The much-heralded 'end of ideology' is still absent; the discursive terrain around the nature and purposes of higher education remains highly contested.

\section{Absent Without Leave: The Sociology of Knowledge}

A key point of this paper is that the Zepke thesis is constructed in ignorance of, or simply ignoring, over a century of debate within the sub-discipline of the sociology of knowledge. Classic authors such as Marx, Weber, Mannheim, Gramsci, Althusser, Berger and Luckmann, Horkheimer, Adorno and Marcuse have grappled with the relationship between 'knowledge', ideology and the social world, between the material and non-material in conditioning how we live and what we think we know. These authors attempted not only to unpick the relative strength and power of structure and agency in this but to develop an account of the relationship between ideas and the social world which has explanatory power. This centred around questions of the ideological power of dominant classes, the role of intellectuals in unmasking it (and whether and how they could do so), the independent role of ideas in changing the world, the power of the state and the media to 'capture' hearts and minds, the significance of and differences between 'high' and 'low' culture, and so on. The language of 'materialism' and 'idealism', 'ideological hegemony', 'relativism', 'social constructionism' and 'material determination' is frequently mobilised in these discussions. Weber's account contributes to that conversation. 
My comments above show that the sophisticated notion of 'elective affinity', originally designed to counter reductive materialist accounts of the relationship between ideas and social groups, has in the Zepke thesis - been reduced to mean, simply, congruence. Weber's account of the process of elective affinity, described above, was not only a partial explanation of why capitalism has thrived in Protestant countries but a considered response to the kind of simplistic dualistic materialism often ascribed to Marx (Thomas, 1985). Weber wanted to show that the 'ruling ideas' referred to in the quote at the head of this paper are not simply an expression of the interests of the dominant class in any socio-economic formation, rather that complex iterative processes occur between material needs and interests, states of mind, sets of ideas and practices. This was, for Weber, an exercise in the sociology of knowledge. The Zepke thesis misses this complexity and offers a simplistic account of knowledge formation and propagation, one very similar to exactly that Weber was arguing against.

Zepke's thesis lacks an explanation of the mechanisms of the relationship between neo-liberalism and student engagement because it is developed outside these debates. Zepke 2014a concludes with a series of statements about what researchers and practitioners in the area of student engagement need to understand and to do, but having no explanation of why they are claimed not to understand and do those things means that such exhortations are likely to be futile. On the face of it they rely on agentic responses at the individual level to a problem which, within the thesis, can be inferred to be structural and deterministic in nature. There is, in short, a theoretical gap in the thesis; content is missing which would go beyond a reductivist misuse of Weber's theory of elective affinity. There is no explanatory purchase in the Zepke thesis because the nature of the relationship between ideologies and the social world is simply assumed, not theorised. And the assumptions are simplistic.

\section{Conclusion}

This paper has argued that the Zepke thesis is based on a very selective approach to the literature and a tendentious interpretation of it. The complex landscape of literature and policy on, attitudes towards, and enactments of student engagement has been simplified into a reductive stereotype. Similarly, the complex contested zone of political and educational ideologies is depicted as neo-liberal totalitarianism, the cardboard cutout version of a turbulent environment of discursive and conceptual struggle. The thesis ignores contextual forces differentially conditioning different 'takes' on student engagement. The ontological underpinning of this version of reality is both over-structuralist and simplistic. It involves an implicit theory of society which brackets out contest and the multiple perspectives that exist in a complex pattern of situated social worlds. It fails to recognise that people are not simply scripted by an ideology but draw on different ideological reservoirs in constructing repertoires of discourse and practices.

\section{References}

Ashwin, P., Abbas, A., and McLean, M. 2012. The Pedagogic Device: Sociology, Knowledge Practices and Teaching-Learning Processes. In Tribes and Territories in the21st-Century: Rethinking the Significance of Disciplines in Higher Education edited by $P$. Trowler, M. Saunders and V. Bamber. 118-129, Abingdon: Routledge. 
Ball, S. 2008.The Education Debate. London: Policy Press.

Barnett, R. 2000. Realising the University. Buckingham: Open University Press.

Booth, S. 1992. Learning to Program: A Phenomenographic Perspective. Gothenburg: Acta Universitatis Gothoburgensis.

Bourdieu, P. 1986. The Forms of Capital. In Handbook of Theory and Research for the Sociology of Education edited by J. Richardson. 241-258, New York: Greenwood.

Brookfield, S. 1986. Understanding and Facilitating Adult Learning. Milton Keynes: Open University Press.

Brown, R. with Corasso, H., 2013 Everything for Sale? : The Marketisation of UK Higher Education. London: Routledge.

Carey, P. 2013. "Representation and Student Engagement in Higher Education: A Reflection on the Views and Experiences of Course Representatives." Journal of Further and Higher Education 37 (1): 71-88

Case, J. and Marshall, D. 2004. "Between Deep and Surface: Procedural Approaches to Learning in Engineering Contexts". Studies in Higher Education 29: 605-615.

Case, J. and Marshall, D. 2005. "'Approaches to Learning' Research in Higher Education: A Response to Haggis”. British Educational Research Journal 31 (2): 257-267.

Deem, R., Hillyard, S. and Reed, M. 2008. Knowledge, Higher Education, and the New Managerialism : The Changing Management of Uk Universities. Oxford : Oxford University Press.

Drew, L., Bailey, S. \& Shreeve, A. 2002. Fashion Variations: Student Approaches to Learning in Fashion Design. In Enhancing Curricula: Exploring Effective Curriculum Practices in Art, Design and Communication in Higher Education edited by A. Davies. 179-198, London: Centre for Learning and Teaching in Art and Design.

Gerth, H. H. and Mills, C. W. trans. eds. 1946. From Max Weber: Essays in Sociology. New York: Oxford University Press.

Haggis, T. 2003. "Constructing Images of Ourselves?" British Journal of Educational Research 29 (1): 89-104.

Haggis, T. 2006. The Implications of Difference. Academy Exchange. Issue 4, 20-21. http://www.heacademy.ac.uk/assets/documents/resources/publications/exchange/web0160 academy exchange issue 4.pdf.

Harper, S .R . and S .J . Quaye, eds . 2009. Student Engagement in Higher Education. New York and London: Routlege.

Haug, K.H. 2006. Students' Development of Assessment Criteria and Enhancement of Learning Potential. Paper presented at the European conference on educational research, September 13-15, University of Geneva.

Higher Education Academy. 2010. Framework for Action: Enhancing Student Engagement at the $\begin{array}{ll}\text { Institutional Level. } & \end{array}$ http://www.heacademy.ac.uk/assets/documents/studentengagement/Frameworkforaction i nstitutional.pdf.

Hockings, C., S. Cooke, H. Yamashita, S. McGinty, and M. Bowl. 2008. "Switched off ? A Study on Disengagement Among Computing Students at Two Universities." Research Papers in Education 23 (2): 191-201.

Ivanic, R. 1998. Writing and Identity: The Discoursal Construction of Identity in Academic Writing. Amsterdam: John Benjamins Publishing. 
Jost, J., C. Federico and J. Napier. 2009. "Political Ideology: Its Structure, Functions and Elective Affinities." Annual Review of Psychology 60: 307-337.

Kahu, E. R. 2013. "Framing Student Engagement in Higher Education." Studies in Higher Education 38 (5): 758-773.

Krause, K.-L. 2005. Understanding and Promoting Student Engagement in University Learning Communities: Engaged, Inert, or Otherwise Occupied? Deconstructing the 21st Century Undergraduate Student. Keynote address at the James Cook University Symposium Sharing Scholarship in Learning and Teaching: Engaging Students. James Cook University, Townsville I Cairns, Queensland, Australia. https://cshe.unimelb.edu.au/resources teach/teaching in practice/docs/Stud eng.pdf.

Krause, K.-L. 2012. Student Engagement: A Messy Policy Challenge in Higher Education. In Engaging with Learning in Higher Education, edited by I. Solomonides, A. Reid, and P. Petocz, 457-474. Oxfordshire: Libri Publishers.

Kuh, G. 2003. "What We're Learning About Student Engagement From NSSE: Benchmarks for Effective Educational Practices.” Change: The Magazine of Higher Learning 35 (2): 24-32.

Mann, S.J. 2001. "Alternative Perspectives on the Student Experience: Alienation and Engagement." Studies in Higher Education 26 (1): 7-19.

Marginson, S. 2013. The Impossibility of Capitalist Markets in Higher Education. Journal of Education Policy 28 (3): 353-370.

Marshall, D. and Case, J. 2005. “'Approaches to Learning' Research in Higher Education: A Response to Haggis." British Educational Research Journal, 31( 2): 257-267.

Marx, K. 1968. A Critique of the German Ideology. First published in full 1932. http://www.marxists.org/archive/marx/works/download/Marx The German Ideology.pdf

Miliszewska, I., and J. Horwood, 2004. Engagement Theory: A Framework for Supporting Cultural Differences in Transnational Education. Proceedings of the HERDSA Conference, July 4_7, in Miri, Malaysia.

Molesworth, M., Scullion, R. and Nixon, E. 2011. (eds.) The Marketisation of Higher Education and The Student as Consumer. London : Routledge.

National Union of Students 2014 A Manifesto for Partnership. London: NUS. http://www.nusconnect.org.uk/campaigns/highereducation/partnership/a-manifesto-for-part nerships/.

Nygaard, C., Stuart Brand, S., Bartholomew, P. and Millard, L. 2013. (eds.) Student Engagement: Identity, Motivation and Community. Faringdon: Libri Publishing.

Quality Assurance Agency. 2012. UK Quality Code for Higher Education - Chapter B5: Student Engagment.

http://www.qaa.ac.uk/Publications/InformationAndGuidance/Pages/quality-code-B5.aspx.

Sabri, D. 2013. Student Evaluations of Teaching as 'Fact-Totems': The Case of the UK National Student Survey. Sociological Research Online, 18 (4) 15. http://www.socresonline.org.uk/18/4/15.html.

Shumar, W. 1997. College For Sale : A Critique of the Commodification of Higher Education. Washington D.C.: Falmer Press.

Slocum, J. \& Rhoads, R.A. 2009. "Faculty and Student Engagement in the Argentine Grassroots Rebellion: Toward a Democratic and Emancipatory Vision of the University." Higher Education The International Journal of Higher Education and Educational Planning 57 (1): 85-105.

Thomas, J. J. R. 1985. “Ideology and Elective Affinity.” Sociology 19 (1): 39-54. 
Thomas, L. 2002. "Student Retention in Higher Education: The Role of Institutional Habitus." Journal of Educational Policy 17 (4): 423-442.

Thomas, L. 2012. Building Student Engagement and Belonging in Higher Education at a Time of Change: Final Report from the What Works? Student Retention and Success Programme. London: Paul Hamlyn Foundation, Higher Education Funding Council for England, The Higher Education Academy and Action on Access.

Trowler, P. 1998. Academics Responding to Change: New Higher Education Frameworks and Academic Cultures. Buckingham: Open University Press/SRHE.

Trowler, V. 2010. Student Engagement Literature Review. York: Higher Education Academy. http://www.heacademy.ac.uk/assets/documents/studentengagement/StudentEngagementL iteratureReview.pdf.

Trowler, V. 2014. Negotiating Contestations and Chaotic Conceptions: Close-up Research into Engaging "Non-Traditional" Students. Paper to the Higher Education Close Up 7 Conference, July, Lancaster University.

University of Lincoln, 2014.2 What We http://studentengagement.blogs.lincoln.ac.uk/what-we-do/

Weber, M. 1992. The Protestant Ethic and the Spirit of Capitalism. Trans, S. Kalberg. New York: Oxford University Press. First published 1930.

Wimpenny, K. And Savin-Baden, M. 2013. "Alienation, Agency and Authenticity: A Synthesis of The Literature On Student Engagement." Teaching in Higher Education 18 (3): 311-326.

Wintrup, J. 2014. Engagement as Dynamic and Relational: Students' Accounts and Achievements Over Time. In C. Bryson (ed.) Understanding and Developing Student Engagment. 64-76 London: Taylor and Francis.

Zepke, N. 2014a. Student Engagement Research in Higher Education: Questioning an Academic Orthodoxy. Teaching Higher Education. DOI: http://dx.doi.org/10.1080/13562517.2014.901956.

Zepke, N. 2014b. What Future for Student Engagement in Neo-Liberal Times? Higher Education. DOI: $10.1007 /$ s10734-014-9797-y. 